\title{
ÖNKORMÁNYZATI GAZDÁLKODÁS ÉS A TERÜLETFEJLESZTÉS AZ ÉSZAKNYUGAT-DUNÁNTÚLON
}

\author{
(Local Government Management and Regional Development in \\ Northwest Transdanubia)
}

\section{LADOS MIHÁLY}

Az Északnyugat-Dunántúl területfejlesztési stratégiájának helyzetfeltáró szakaszán belül egy olyan kísérletre is vállalkoztunk, amelyben igyekeztünk fölmérni a gazdaság fó aktorainak - vállalkozások, költségvetés, háztartások - hozzájárulását a régió megyéinek területfejlesztéséhez (I. ábra). Rendkívül izgalmasnak tünt ez a vállalkozás, hiszen az országban kitapinthatóak a gazdasági fejlödés regionális kủlönbségei. Ugyanakkor alig van tényleges információnk arról, hogy valójában milyen erőforrásokból táplálkozott az elmúlt három-négy évben az egyes térségek területfejlesztése.

A felszínen úgy tủnik, hogy a központi erőforrások döntő hányada az elmaradott, illetve a válsággal terhelt régiókba áramlik a hatékonyság mérsékelt eredményét fölmutatva. Ugyanakkor az ország más térségei - pl. az Északnyugat-Dunántúl - a hazai átlagos viszonyokhoz képest látványos fejlődést mutatnak, látszólag jelentősebb kormányzati támogatás nélkül. Jelen tanulmányban nem foglalkozunk a gazdaság valamennyj szereplőjével, csupán az önkonnányzati gazdálkodás és a területfejlesztés kapcsolatát elemezzük.

De mit is értettünk a vizsgálat során területfejlesztés alatt? Számunkra a területfejlesztés egy adott térség jóléti szintjének a fönntartását, emelését jelenti. A mérhetőség érdekében a területfejlesztést kísérletünk során ekvivalensnek fogtuk föl a beruházási, felhalmozási tevékenységgel. Magát a mérést két oldalról igyekeztünk elvégezni. Egyrészt mértük a beruházás szintjét és mértékét, másrészt megpróbáltuk meghatározni a megvalósult beruházások eszközrendszerét.

\section{Az önkormányzati gazdálkodảs jellemzői Északnyugat-Dunántúlon}

Az önkormányzati rendszer kialakulásának egyik sajátossága az volt Magyarországon, hogy sokféle közszolgáltatási feladat került helyi szintre. A pénzügyi adatok azt mutatják, hogy a helyi önkormányzatok a hazai gazdasági folyamatok meghatározó szereplöivé váltak a kilencvenes évek elsó felében (1. táblázat). Ez részben a reálértékben zsugorodó GDP következménye, másoldalról az önkormányzati gazdálkodásra való áttérés, a kormányzati decentralizáció időben történő széthúzódásának a hatása. 
1. ÁBRA

A területfejlesztés modellje

The model of regional development

A területfejlesztés szereplöi
A területfejlesztés

finanszírozása

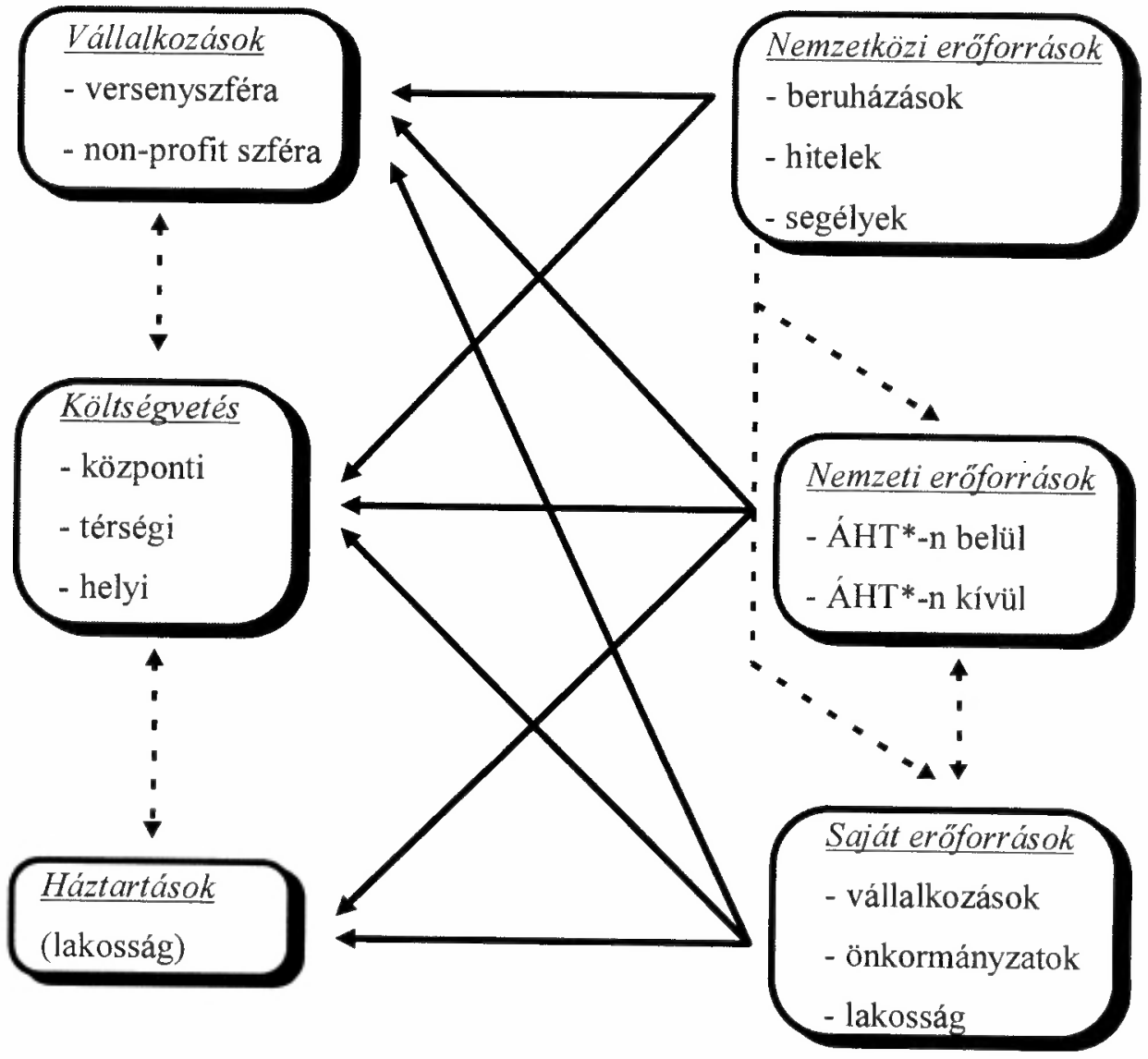

* ÁHT - Államháztartás

Forrás: Lados (1995) 
Önkormányzati gazdálkodás és...

\section{TÁBLÁZAT}

A helyi önkormányzatok kiadásai a GDP \%-ában, 1990-1994

Local government expenditure as in per cent of GDP, 1990-1994

\begin{tabular}{|c|c|c|c|}
\hline Év & $\begin{array}{c}\text { GDP (folyó áron, Mrd } \\
\mathrm{Ft} \text { ) }\end{array}$ & $\begin{array}{c}\text { Az onkormányzatok } \\
\text { tárgyévi kiadásai (Mrd Ft) }\end{array}$ & $\begin{array}{c}\text { Tárgyévi kiadások a GDP } \\
\text { százalékában (\%) }\end{array}$ \\
\hline 1990 & 2089 & 311 & 14,9 \\
1992 & 2805 & 505 & 18,0 \\
1994 & 3960 & 813 & 20,5 \\
\hline
\end{tabular}

Forrás: Vígvári (1994), Pitti-Varga (1995) és Világbank (1995) adatai alapján

A forrásorientált szabályozáshoz való alkalmazkodás nem volt lehetséges egy év alatt. (Természetesen ez nem is lehetett elvárás.) A gyengülő bevételi lehetőségek reálértéken csökkenő normatív támogatások 1993-tól - mellett folytatódott a helyi kiadások expanziója. Ez egyfelöl a központi feladatok egyre bővülö helyi szintre történỏ decentralizálásából fakadt, másfelöl még tovább éltek a kiadásorientált pénzügyi tervezés reflexei. Így a rendszer müködésének első időszakában rendszerint elmaradt a feladatok átvilágítása. Lényeges tényezöként kell említeni az inflációt is, amely folyamatosan meghaladta a $20 \%$-ot az elöző önkormányzati ciklusban.

A helyi költségvetési stratégiák egyrészt a korábban felhalmozódott maradványok fölélésével, másrészt többletbevételekkel - mindenekelött vagyon (ingatlan) értékesítéssel, helyi adó(k) bevezetésével, késöbb hitelfelvétellel -, harmadrészt a felhalmozási ráforditásaik elhagyásával, elhalasztásával igyekeztek a szükséges pénzügyi egyensúlyt megteremteni. Ezek a lépések azonban nem bizonyultak elég hatékonynak, mivel az önkormányzatok éves pénzügyi egyenlege 1991 óta folyamatosan romlik, sőt 1993 óta negatív. Ez a trend az Északnyugat-Dunántúl önkormányzatainak összességére is jellemző (2. ábra). 
Önkormányzati gazdálkodás és a területfejlesztés az Északnyugat-Dunántúlon Tér és Társadalom, 11. 1997. 1.197-217. p.

200 Lados Mihály TÉT 1997 - 1

\section{2. ÁBRA}

Az egy före jutó tárgyévi bevételek és kiadások egyenlege (Ft/fö)

Balance of revenues and expenditure per person in the given year HUF/person

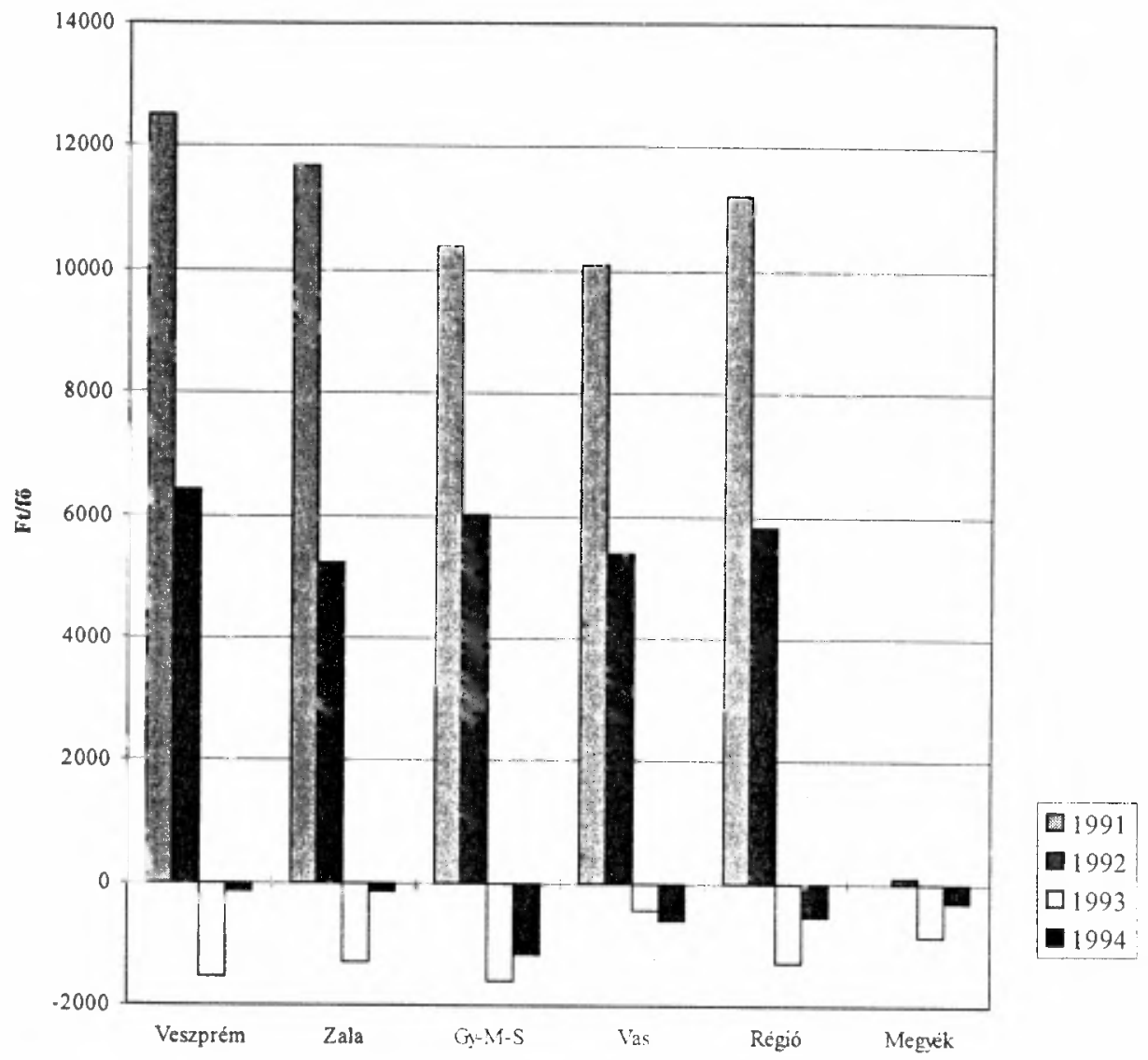

Forrás: TÁKISZ adatbázis alapján 


\section{A területfejlesztés mértéke az Északnyugat-Dunántúlon}

\section{A régió helye a nemzetgazdasági beruházásokban}

A vidéki nemzetgazdasági beruházások 20-25\%-a realizálódik régiónkban (2. táblázat). Ez azt jelenti, hogy az Északnyugat-Dunántúl megyéiben a lakossági részarányukhoz $(16,6 \%)$ képest a beruházások 25-40\%-kal magasabb koncentrációja volt jellemző a kilencvenes évek elsö harmadában. A régió azonban nem homogén ebben a tekintetben. Gyốr-Moson-Sopron megye tőkevonzása fokozódott a jelzett időszakban, Vasé, Veszprémé és Zaláé hullámzik. Vas megye kiugró 1992. évi részesedését a GM Opel szentgotthárdi gyárának üzembe helyezése okozhatja. Zala megye pozíciója folyamatosan romlott, sőt 1993-ban a beruházások koncentrációs szintje a megye népesség koncentrációs mutatója alá csökkent ebben a megyében. Veszprém megyére 1992-ben és 1994-ben is megfigyelhető egy ilyen visszaesés.

\section{TÁBLÁZAT}

Az Északnyugat-Dunántúl részese dése a megyék nemzetgazdasági beruházásaiban, 1991-1994 (\%)

Share of Nortwest Transdanubia in the public investments by the counties, 1991-1994 (in per cent)

\begin{tabular}{|l|c|c|c|c|c|}
\hline Megyék & 1991 & 1992 & 1993 & 1994 & Népesség* \\
\hline Györ-Moson-Sopron & 7,0 & 7,1 & 8,7 & 10,1 & 5,1 \\
Vas & 5,7 & 9,3 & 4,8 & 4,0 & 3,2 \\
Veszprém & 5,3 & 4,3 & 5,3 & 4,3 & 4,6 \\
Zala & 4,9 & 4,3 & 3,4 & 4,2 & 3,7 \\
\hline Régió & 22,9 & 25,0 & 22,2 & 22,6 & 16,6 \\
\hline
\end{tabular}

* Az egyes megyék aránya az osszes vidéki népességében, 1991-1993 (\%)

Forrás: Beretvásné (1995) alapján saját számítás

1991-1994 között - folyó áron - mintegy 300 Mrd Ft-ot ruháztak be a régióban (3. táblázat). Ennek több, mint egyharmada valósult meg Györ-Moson-Sopron megyében $(111 \mathrm{Mrd} \mathrm{Ft).} \mathrm{A} \mathrm{megye} \mathrm{egyenletes} \mathrm{növekedést} \mathrm{mutat,} \mathrm{továbbá} \mathrm{az} \mathrm{egy} \mathrm{före}$ jutó beruházások tekintetében évröl évre messzebbre hagyja el a vidéki átlagot. A beruházások fajlagos értékét tekintve Vas megye teljesítménye is figyelemre méltó, a vidéki átlag több mint másfélszeresével, de a már korábban említett évenkénti hullámzással. Veszprém és Zala megye értékei is a vidéki átlagot meghaladóak, de teljesítményük nem annyira kiugró, mint az elöbbi két megyéé. 


\section{TÁBLÁZAT}

A nemzetgazdasági beruházások alakulása az Északnyugat-Dunántúlon, 1991-1994

Public investments in Nortwest Transdanubia, 1991-1994

\begin{tabular}{|l|r|r|r|r|r|r|r|r|r|r|}
\hline & \multicolumn{5}{|c|}{ Beruházások (Mrd Ft) } & \multicolumn{4}{|c|}{ Egy före jutó beruházások (eFt/fö) } \\
\hline & 1991 & 1992 & 1993 & 1994 & $1991-1994$ & 1991 & 1992 & 1993 & 1994 & $1991-1994$ \\
\hline Gy-M-S & 15,6 & 21,8 & 28,7 & 44,4 & 110,5 & 35,9 & 49,6 & 65,7 & 104,1 & 255,3 \\
\hline Vas & 12,9 & 28,7 & 15,8 & 17,3 & 74,7 & 46,2 & 103,3 & 56,9 & 63,6 & 270,0 \\
\hline Veszprém & 12,0 & 13,3 & 17,4 & 18,7 & 61,4 & 30,9 & 34,6 & 45,2 & 49,5 & 160,2 \\
\hline Zala & 10,9 & 13,1 & 11,0 & 18,5 & 53,5 & 34,7 & 41,9 & 35,3 & 61,4 & 173,3 \\
\hline Régió & 51,4 & 76,9 & 72,9 & 98,9 & 300,1 & 36,3 & 54,4 & 51,6 & 71,7 & 214,0 \\
\hline Megyék & 224,2 & 307,4 & 328,9 & 437,3 & 1297,8 & 26,1 & 35,8 & 38,3 & 52,7 & 152,9 \\
\hline
\end{tabular}

Forrás: Beretvásné (1995) alapján saját számítás

Az önkormányzatok részesedése a nemzetgazdasági beruházásokban a vidék átlagát tekintve $14 \%$ a vizsgált időszakban. A régió megyéi ezen átlag körül mozognak. Vas megye $2 \%$-kal elmarad attól, míg Veszprém megye 3\%-kal meghaladja azt. GyőrMoson-Sopron és Zala megye az átlagnál helyezkedik el.

\section{Az önkormányzatok felhalmozási tevékenysége az Északnyugat-Dunántúlon}

A legutóbbi időszakban sokan az őnkormányzati gazdaságot tartották a hazai gazdaság húzó ágazatának (ILLÉS 1993). A felhalmozódott infrastrukturális hiányok pótlását minden települési önkormányzat alapcélként jelölte meg az előzó választási ciklus elején. Vezetékes vizellátás, csatornázás, gázellátás, uitépítés és a telefonhálózat bóvítése, kiterjesztése jellemezte ezt az időszakot. A kitủzött célokat a cél- és címzett támogatások, valamint az elkülönitett alapok rendszere is segitette, ösztönözte. Mivel ezek a támogatási rendszerek - igaz eltérö mértékben - saját források biztositását is igényelik, a települési önkormányzatok egy része - helyi politikai programjuk megvalósítása érdekében - erején felül vállalt fejlesztési feladatokat. A szükséges saját részt számos esetben hitelböl fedezték. Ez néhány önkormányzatnál súlyos eladósodást eredményezett ${ }^{1}$.

Valójában mekkora értékről van szó? A vidéki önkormányzatok az 1991-1994. évi ciklusban folyó áron mintegy 332 Mrd Ft-ot, 1991. évi árszinten számolva $238 \mathrm{Mrd}$ Ft-ot fordítottak fejlesztésre. Az időszak átlagában ez az összes önkormányzati kiadás $18,9 \%$-a (4. táblázat). Az időszakon belül az 1992. év volt a csúcs, amikor a fejlesztési kiadások részaránya meghaladta a $20 \%$-ot. A többi évben a fejlesztések 18,0-18,5\% között, tehát egy viszonylag stabil és enyhén fölfelé ivelő sávban mozogtak.

Az o̊sszesen 63,2 Mrd Ft-ot beruházó északnyugat-dunántúli megyékben a fenti trendtöl valamelyest eltéró folyamatok zajlottak ugyanebben az időszakban. A ciklus elsó két évében a fejlesztés részaránya a vidéki átlagtól elmaradt, a ciklus második felében viszont egyre magasabb értékkel felette volt. A térségen belúl 
Veszprém megye lóg ki a sorból, csökkenő fejlesztési kiadási trendet mutatva. Ugyanakkor az 1992. évtöl eltekintve (15,7\%) viszonylag szük - 20,5\%-19,4\%-os sávban mozogtak a fejlesztés arányai az egyes években.

Nem mondható el ez Györ-Moson-Sopron megyéröl, ahol rendkívül erös a fejlesztések fluktuációja. Az idöszak kezdö és záró éve között 10 százalékpontnyi különbség van. Ezt az erös mozgást részben az magyarázza, hogy 1992-re futottak ki a megye vezetékes vízellátási programjai, míg az újonnan induló csatorna- és gázhálózat fejlesztési programok 1994, évet terhelték eröteljesebben.

\section{TÁBLÁZAT}

Fejlesztési kiadások aránya a tárgyévi kiadásokban, 1991-1994 (\%)

Share of expenditure on development from the annual expenditure, 1991-1994 (in per cent)

\begin{tabular}{|l|c|c|c|c|c|}
\hline Megyék & 1991 & 1992 & 1993 & 1994 & Együtt \\
\hline Györ-Moson-Sopron & 14,3 & 20,0 & 18,0 & 24,3 & 20,1 \\
\hline Vas & 16,2 & 19,5 & 18,6 & 20,2 & 19,0 \\
\hline Veszprém & 20,5 & 15,7 & 19,8 & 19,4 & 18,6 \\
\hline Zala & 17,5 & 21,9 & 19,8 & 21,5 & 20,5 \\
\hline Régió összesen & 17,1 & 18,9 & 19,0 & 21,5 & 19,6 \\
\hline Megyék összesen & 18,2 & 20,5 & 18,4 & 18,3 & 18,9 \\
\hline
\end{tabular}

Forrás: TÁKISZ adatbázis alapján saját számítás

Vas és Zala megyében hasonló tendencia figyelhetố meg, de a változások amplitúdója lényegesen kisebb. Ezek a viszonylag erős ingadozások két dologra hívják föl a figyelmet. Egyrészt valószínủsítik, hogy a térség fejlesztési programjai erösen központi támogatási programhoz kötöttek. Másrészt - mivel az egyes programok különbözö mértékig támogatottak - a kiadási igények ilyen mérvü változása csak hitellel fedezhetö. Ugyanis a saját források képzésében - különösen a helyi adók tekintetében - nem kívánatos, ha évről évre jelentős oda-vissza ugrások jelentkeznek. Az ilyen változások az adókulcsok évenkénti nagymértékü módositását igénylik, ez pedig egyrészt politikailag rendkívü] érzékeny terület (háztartások), másrészt rontja a helyi gazdaság teljesítőképességét.

\section{A fejlesztések forrásrendszere}

Az elmúlt négy év önkormányzati gazdálkodásának fontos jellemzője volt a gyarapodó decentralizált feladatok köre. A feladatátadással források is jártak, ezek azonban rendszerint csupán részlegesen fedezték annak költségeit ${ }^{2}$. A hiányzó rész fedezetét a szabad források (átengedett bevételek, sajátos helyi bevételek: helyi adók, ingatlan hasznosítás, illeték bevételek stb.) jelenthették. Ezek már eddig is terheltek voltak a már korábban az önkormányzatnak juttatott kötelezỏ, valamint az önként vállalt feladatok múködtetésével. Így minden új részleges forrással átadott feladat (pl. tüzoltóság 1995. július 1-töl) növeli a feszültséget a meglévő szolgáltatásỉ rendszer müködtetése, valamint a településfejlesztés lehetőségei között. 
Potenciálisan a következő források szolgálhatják az önkormányzatok fejlesztési, felhalmozási törekvéseit:

- cél- és címzett támogatások;

- egyéb támogatási rendszerek (elkülönített alapok);

- megosztott adóbevételek (SZJA megosztás és SZJA kiegészítés);

- saját bevételek (helyi adók, felhalmozási és tőke jellegủ bevételek);

- pénzeszköz átadások (ÁHT-n belül: kormányzati szervek, más önkormányzatok; ÁHT-n kívül: lakosság, vállalkozások);

- hiteljellegü bevételek.

Nem elemezzük teljes körúen a fenti forráselemeket. A vizsgálat során három kérdésre koncentráltunk, s ezekhez a kérdésekhez rendeltünk egy-egy forrástényezót:

1. Milyen mértékben támogatottak a régióban megvalósított önkormányzati fejlesztések? - cél- és címzett támogatások;

2. Mekkora volt a saját rész potenciảlis kapacitása az adott időszakban? - helyi adók, felhalmozási és tỏke jellegú bevételek;

3. Milyen mértékű eladósodással járt a térség fejlesztési programjainak a megvalósítása? - hitel jellegü bevételek és adósságszolgálat.

\section{Fejlesztési támogatások}

Az Országgyưlés egyes nagy költségigényü fejlesztési feladatok megvalósítására meghatározott helyi önkormányzatoknak címzett támogatást nyủjthat, amely meghatározott célra fordítható. Az elmúlt időszakban a preferảlt címek, színház és kórház rekonstrukciók voltak. A céltámogatások társadalmilag kiemelt célok megvalósítását segíthetik elö. Ezen célok kijelölésérōl az Országgyưlés dönt. A célonkẻnti támogatások mértékét és feltételeit tờrvény szabályozza.

A címzett és céltámogatások mindössze 4\%-ot képviselnek az önkormányzatok forrásain belül, jelentőségùk azonban nagy az önkormányzati szabályozásban. Évente 50-100 Mrd Ft összegủ beruházást mozgatnak meg.

A szabad, müködési kiadási szükségletekkel nem terhelt saját források szükségessége miatt elsősorban a kedvezöbb jövedelmi pozicióban lévõ önkormányzatok tudnak pályázni valamely célra. Az elmúlt évtizedekben fölhalmozódott infrastrukturális hiányok azonban arra kényszerítik a helyi politikát, hogy akár a bukás veszélyét is vállalva, de belevágjanak valamely cél megvalósításába. A legáltalánosabb veszélyek ezzel a rendszerre! kapcsolatban a következök:

- folyó feladat ellátásától vonnak el forrásokat a saját rész megteremtése érdekében;

- hitelből fedezik a saját részt, nem tỏrỏdve vajon adott-e a hitel visszafizetésének a lehetősége;

- az elkészült objektum ưzemeltetésére nincsen forrás.

Az elmúlt négy évben a két támogatás egyưttesen közel 100 Mrd Ft-ot juttatott az önkormányzatoknak, amelynek kơzel 90\%-a a vidéki ơnkormányzatok forrásait gyarapította. Ebból az Északnyugat-Dunántúl megyéi mintegy 20,0 Mrd Ft-tal részesedtek. Ez a négy év vidéknek juttatott cél- és címzett támogatásainak 23,5\%-a (!). Ráadásul az időszakon belül ez nỏvekvő tendenciát mutat (5. táblázat). 


\begin{abstract}
5. TÁBLÁZAT
Cél - és címzett támogatások az Északnyugat-Dunántúl megyéiben, 1991-1994 (MFt)
\end{abstract}

Targeted and addressed grants in the Nortwest Transdanubian counties, 1991-1994 (million HUF)

\begin{tabular}{|l|c|c|c|c|c|c|}
\hline Megyék & 1991 & 1992 & 1993 & 1994 & Együtt & $\begin{array}{c}\text { Arány } \\
(\%)^{*}\end{array}$ \\
\hline Györ-Moson-Sopron & 911,5 & 1377,3 & 808,3 & 2876,9 & 5974,0 & 31,4 \\
\hline Vas & 534,9 & 594,2 & 604,2 & 751,2 & 2484,5 & 21,2 \\
\hline Veszprém & 1018,4 & 1404,0 & 1897,1 & 2163,0 & 6482,5 & 36,9 \\
\hline Zala & 725,2 & 1182,2 & 1152,4 & 2033,3 & 5093,1 & 34,2 \\
\hline Régió összesen & 3190,0 & 4557,7 & 4462,0 & 7824,4 & 20034,1 & 31,7 \\
\hline Megyék ósszesen & 14849,4 & 20439,8 & 19307,0 & 30791,8 & 85388,0 & 25,7 \\
\hline Régió/Megyék arány (\%) & 21,5 & 22,3 & 23,1 & 25,4 & 23,5 & \\
\hline
\end{tabular}

* Támogatási szint = A cél- és címzett támogatások aránya a fejlesztési, felhalmozási kiadásokban

Forrás: TÁKISZ adatbázis alapján

A régión belül Veszprém megye önkormányzatai tünnek a legaktívabb pályázóknak a térségen belül, az összes vidéki támogatás 7,6\%-ának fölhasználásával. Ez azonban csalóka, mivel az ide érkező támogatások közel kétharmada címzett támogatás volt, amely döntően a kórház-rekonstrukciókat finanszírozta az elmúlt idöszakban. Ez pedig csak az önkormányzatot egy szükebb körét (megyei és városi önkormányzatok) érinti.

Györ-Moson-Sopron megye települései viszont az összes vidéki támogatás 7,0\%át, ezen belül a céltámogatások $9,7 \%$-át nyerték el. A támogatások egyenetlenül oszlottak meg a négy év során, azok közel fele 1994-re esett. Ennek oka, hogy az idöszak első felében a kisebb költségigényú vízközmü programok fejezódtek be a megyében. Ugyanakkor egy erōteljes csatornázási program indult meg az évtized elején, amely eddig az 1994. év települési beruházásaiban csúcsosodott.

Zala megye szintén a jelentős támogatást élvezö megyék közé tartozott a vizsgált négy évben. Ebben a megyében is 1994-re csúcsosodtak az önkormányzati beruházások. Habár a megyébe érkezô támogatások évröl évre emelkednek, Vas megye mégis lefelé húzza régió átlagát. A térségben egyedül itt kisebb a cél- és címzett támogatások aránya, mint a megye népességaránya a vidéki népességben.

Már a támogatások abszolút összegei is jelezték, hogy elöfeltevéseinkkel szemben ez a támogatási rendszer nem feltétlenül a gazdaságilag gyengébben álló megyékbe pumpálta a forrásokat. Ez különösen a céltámogatási rendszernél figyelhetö meg. A felhasznált fajlagos támogatások oly sok más, a területi struktúrát elemzö adatsorhoz hasonlóan, egy nyugat-kelet irányú eloszlást mutatnak a térképen (3. ábra). Ennek magyarázatát a támogatás elnyeréséhez szükséges (potenciális) saját erő közötti különbségek adhatják. Végülis a régió önkormányzatainak mintegy kétharmada jutott forráshoz a céltámogatási rendszerból, s azok döntó hányada a vidéki átlagot meghaladó fajlagos értékkel. 


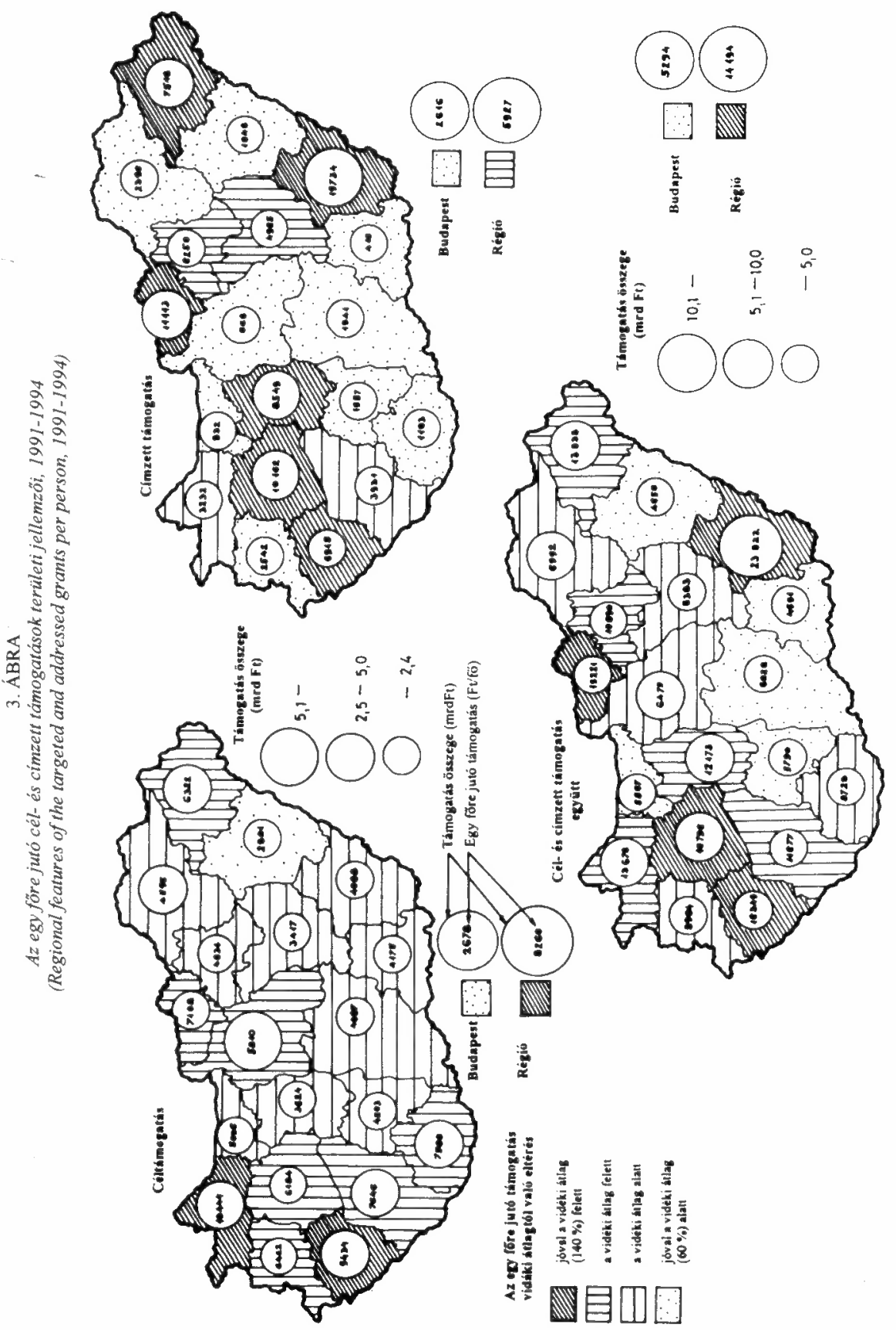


A címzett támogatások fajlagos területi eloszlása lényegesen diverzifikáltabb képet mutat. Ez érthetö is, hiszen lényegében egy speciális terület, az egészségügy felhalmozási programját támogatta. Ennél a támogatásnál valamelyest érzödik a "kormány programos megyéknek" (Békés, Nógrád, Szabolcs-Szatmár-Bereg) figyelembe vétele a támogatási igények elbirálásánál. Még így is a térség két megyéje (Veszprém, Zala) bekerült a magasan preferált térségek közé a címzett támogatásokon belül a vizsgált időszakban.

A fejlesztési programok támogatottsági szintje Veszprém és Zala megyében volt az átlagosnál kiugróbb (5. táblázat). Ez azzal a magyarázható, hogy mindkét megyében a címzett támogatások magas állományt képviseltek az idöszak során. Ennél a támogatási formánál viszont lényegesen magasabb a lehetséges központi hányad. Egyes esetekben a $90 \%$-ot is elérheti. Ugyanakkor a céltámogatásos közmü programoknál a támogatási arány többnyire nem haladhatta meg a 40\%-ot ${ }^{3}$. GyörMoson-Sopron megye támogatottsági szintje - magas cél- és közepes címzett támogatási állomány mellett - szintén jóval a megyék átlaga fölött helyezkedik el.

Vas megye értéke az átlagostól lényegesen - 4,5 százalékponttal - elmarad. A megye önkormányzatainak összes felhalmozási, fejlesztési kiadási szintje - ha a régió többi megyéjéhez képest kisebb mértékben is -, de meghaladják a vidék átlagát. Ez azt jelenti, hogy ennek a megyének a települései kevésbé tudtak bekapcsolódni a cél- és címzett támogatási rendszerbe. Így az átlagosnál valamelyest erősebb beruházási ráta megvalósításához az átlagosnál lényegesen magasabb arányú saját vagy más egyéb forrás (hitel, pénzeszközök átvétele) biztositása volt szükséges, mint a többi megyében.

\section{Saját források}

\section{a) Helyi adók}

A megreformált helyi adó rendszer 1992. január 1-től lépett hatályba oly módon, hogy ezzel egyidejüleg valamennyi korábbi lakossági adó, valamint a telekhasználati és igénybevételi díj megszűnt. Az új adók alkalmazása már 1991-től lehetséges volt, ezzel azonban csak az önkormányzatok alig több mint egy tizede élt (Lados 1994). Így 1991-ben, a szabályozás átmeneti éveként, párhuzamosan múködött a két rendszer. 1995-re az önkormányzatok több, mint fele használta ki a helyi adóztatás jogát (Fehérvári 1995). Söt számos önkormányzat több adófajtát is bevezetett a törvény ${ }^{4}$ által biztositott lehetőségek közül: építményadó, telekadó, kommunális adó, idegenforgalmi adó, iparüzési adó.

Az országos trend Északnyugat-Dunántúl megyéiben is jellemzö volt, napjainkra a térség önkormányzatainak jelentős hányada vetett ki egy vagy több helyi adót. A helyi adót alkalmazó települések a régió egyes megyéiben azonban a vidék átlaga $(52,0 \%)$ alatt helyezkednek el. A legalacsonyabb a bevezetettség Vas megyében $(39,8 \%)$, míg Veszprém megye $(49,8 \%)$ megkőzelíti a megyék átlagát. Mivel a térség mindegyik megyéjében szép számmal található kis lélekszámú, gyenge gazdasági bázisú település is, ezért a fenti mutatónál lényegesebb, hogy ténylegesen mekkora bevételt generáltak az új helyi adók, s azok milyen jelentöséggel bírnak a helyi költségvetésekben (6. táblázat). 
Vas és Zala megye helyi adó bevételi szinvonala elmarad a megyék átlagától. Az ebböl a forrásból származó felhalmozás finanszírozási kapacitásuk is jóval az átlagos érték alatt marad. Zala megye esetében ez kevésbé zavaró, hiszen viszonylag magas címzett támogatású beruházási állománya. Györ-Moson-Sopron megye értéke $10 \%$-kal, Veszprém megyéé másfélszeresen a vidék átlaga fölött van.

A kedvezö összehasonlító mutatók sem takarhatják azonban azt, hogy még ezekben a megyékben is a helyi adókból származó bevételek jelenleg csak kisebb hányadát lennének képesek finanszírozni egy-egy beruházási projektnek. Igaz a teljes finanszírozás nem is várható el ettöl a forrástól, hiszen az egyes beruházások teljesítés kifizetései lökésszerúen jelentkeznek. Ezért a helyi adók, nagyobb projektek esetében a szükséges hitelfelvétel adósságszolgálatát biztosithatják.

\section{TÁBLÁZAT \\ Helyi adó bevételek az Északnyugat-Dunántúl megyéiben, 1991-1994 (MFt) \\ Local tax revenues in the Nortwest Transdanubian counties,} 1991-1994 (million HUF)

\begin{tabular}{|l|c|c|c|c|c|c|}
\hline Megyék & 1991 & 1992 & 1993 & 1994 & Együtt & $\begin{array}{c}\text { Arány } \\
(\%)^{*}\end{array}$ \\
\hline Györ-Moson-Sopron & 355,2 & 605,9 & 903,6 & 1120,7 & 2985,4 & 15,7 \\
\hline Vas & 101,0 & 217,8 & 469,4 & 724,1 & 1512,3 & 12,9 \\
\hline Veszprém & 322,5 & 753,8 & 1071,6 & 1264,1 & 3412,0 & 19,4 \\
\hline Zala & 164,9 & 357,8 & 502,6 & 648,6 & 1673,9 & 11,3 \\
\hline Régió összesen & 943,6 & 1935,3 & 2947,2 & 3707,5 & 9533,6 & 15,1 \\
\hline Megyék összesen & 7876,1 & 9548,1 & 14425,3 & 18514,2 & 50363,7 & 15,2 \\
\hline Régió/Megyék arány (\%) & 12,0 & 20,3 & 20,4 & 20,3 & 18,9 & \\
\hline
\end{tabular}

* A fejlesztési kiadások potenciális onneró szintje = A helyi adó bevételek aránya a felhalmozási, fejlesztési kiadásokban.

Forrás: TÁKISZ adatbázis alapján

A megye általános helyi adózási képét jelentősen módosíthatja az adóbevételek település típusonkénti koncentrációja. Országosan jellemzö az adóbevételek nagyobb településekbe, elsösorban a városokba való koncentrációja. A vidék egészében a városok az adóbevételek $82 \%$-át szedték be 1994-ben. Lényegesen meghaladta ezt a szintet Györ-Moson-Sopron megye (90\%). Vas megye (85\%) és Zala megye (79\%) a vidéki átlag körül helyezkedik el. Mindhárom megyére és a vidék egészére is igaz így, hogy a helyi adók ma, jellemzően a városi önkormányzatok fejlesztési programjaihoz képesek érzékelhető mértékben is hozzájárulni.

Veszprém megyében a nagyszámú városi település ellenére a fenti koncentrációs mutató $69 \%$. Mivel az összes adóbevételben is ez a megye vezeti a régiót (3,4 Mrd Ft), ezért vélhetöen itt a községi önkormányzatok egy része is komolyabban számolhat a helyi adókból származó bevételekkel fejlesztéseik, illetve fejlesztési célú pályázataik tervezésénél. Veszprém megye kedvezőbb községi adóbevételi részesedése a Balaton parti települések aktív adóztató politikájából ered. A parti sáv 
minden önkormányzata vetett ki helyi adót és jelentós hányaduk három-négy adótípust is bevezetett a lehetséges öt alap adó közül.

b) Felhalmozási és tőke jellegủ bevételek

A felhalmozási és tőke jellegủ bevételek közül a legfontosabbak: az immateriális javak értékesítéséból származó bevételek, az osztalék- és hozambevételek, az üzletrészek és az értékpapírok értékesitéséböl származó bevételek, valamint a privatizációs bevételek. Lényegében az önkormányzati vagyonnal történõ gazdálkodásból származó bevételek. Ezek mindegyike a településfejlesztés forrása lehet, ha más feladat finanszírozása azokat nem terheli.

Országosan ez a bevételi csoport mutatja a legerősebb dinamikát, 1991. és 1994. között közel az ötszörösére - 10,9 Mrd Ft-ról 51,0 Mrd Ft-ra - emelkedett. Területi bontásban csupán az 1993. és 1994. évi adatok állnak a rendelkezésünkre. Ebben a két évben képződött e források több mint $70 \%$ a, így a két év adatsora nagymértékben tükrözi az egész időszakra jellemzö területi eloszlást.

A vidék és Budapest között nagyjából fele-fele arányban oszlottak meg a vagyonhasznosításból származó bevételek. Tendenciáját tekintve azonban fokozatosan emelkedik a vidék részesedése. Mivel ezek a források szinte kizárólag valamely vagyontárgy értékesítéséböl származó bevételek, ezért rohamos növekedésük valószínüleg inkább kényszerủ vagyon felélésnek tekinthetô, mint ésszerü vagyongazdálkodás eredményének. (A vidéki önkormányzatok eszköz és ingatlan bérletből származó bevétele a vagyon értékesitési bevételek valamivel több mint egynegyedét tették ki 1993-1994. években.)

Az Északnyugat-Dunántúl megyéiben összesen 8,6 Mrd Ft felhalmozási bevétel keletkezett a vizsgált időszakban, ez a megyék összes ilyen jellegủ bevételének több mint egyötöde (7. táblázat). A két évet tekintve a térség részesedése fokozódott a bevételi típusban. Összegét tekintve Györ-Moson-Sopron megye jár az élen a térségen belül, fajlagos értékét tekintve azonban Zala megyéé a vezetö szerep.

\section{TÁBLÁZAT}

Felhalmozási és töke jellegü bevételek az Északnyugat-Dunántúl megyéiben, 1993-1994 (MFt)

Accumulation and capital incomes in the Nortwest Transdanubian counties, 1993-1994 (million HUF)

\begin{tabular}{|l|c|c|c|c|c|}
\hline Megyék & 1993 & 1994 & Együtt & $\begin{array}{c}\text { Részarány a } \\
\text { megyékben } \\
(\%)\end{array}$ & $\begin{array}{c}\text { Arány } \\
(\%)^{*}\end{array}$ \\
\hline Gyór-Moson-Sopron & 928,6 & 1500,1 & 2428,7 & 6,0 & 19,6 \\
Vas & 486,7 & 1206,7 & 1693,4 & 4,2 & 23,2 \\
Veszprém & 672,0 & 1552,9 & 2224,9 & 5,5 & 21,1 \\
Zala & 648,5 & 1653,6 & 2302,1 & 5,7 & 25,1 \\
Régió összesen & 2735,8 & 5913,3 & 8649,1 & 21,3 & 22,0 \\
\hline Megyék osszesen & 14464,1 & 26155,8 & 40619,9 & & 21,3 \\
Régió/Megyék arány (\%) & 18,9 & 22,6 & 21,3 & & \\
\hline
\end{tabular}

* A fejlesztési kiadások potenciális öneró szintje = Felhalmozási és tőke jellegủ bevételek aránya a felhalmozási, fejlesztési kiadásokban (1993-1994).

Forrảs: TÁKISZ adatbázis alapján 
Megfigyelhetö, hogy a vagyonhasznosításból származó bevételek és a helyi adók között egyfajta komplementer hatás müködik. Azokban a megyékben, ahol a helyi adó kapacitás kedvezőbb értékeket mutat (Györ-Moson-Sopron és Veszprém megye), ott a felhalmozási bevételeknek relative kisebb a potenciális súlya a fejlesztési kiadásokban. Azokban a megyékben pedig, ahol az adókapacitás alacsonyabb mértékủ, ott az átlagot meghaladó a felhalmozási bevétel.

\section{Hitelforrások}

A hitel szabályozása folyamatosan vált liberálisabbá a tanácsi, majd az önkornányzati gazdálkodásban. A szabályozás 1990 és 1995 között kevés kötöttséget tartalmazott a hitel fölvétellel, illetve a kötvény kibocsátással kapcsolatban. A támogatott kamatok megszünése azonban kemény költségvetési korlátot szabott az önkormányzatok számára a kilencvenes évek első két évében. A kamatfeltételek ma sem sokkal kedvezőbbek (30-35\%), de a szabályozás más elemei - elsősorban a közalkalmazotti/köztisztviselöi bér-tarifa rendszer bevezetése a mủködés, illetve a cél- és címzett támogatások rendszere a fejlesztés területén - mégis a hitelek felé fordították az önkormányzatok figyelmét. Míg 1991-ben és 1992-ben összesen $8,7 \mathrm{Mrd} \mathrm{Ft}$ müködési és fejlesztési hitelt vettek föl az önkormányzatok, addig 1993-ban mind a két hitelfajta állománya több mint 8,0 Mrd Ft-tal gyarapodott. A tetôpontot az 1994. év érte el eddig. A vidék önkormányzatai együttesen 20,4 Mrd Ft fejlesztési hitelt használtak föl beruházásaik megvalósításához. Vagyis a vidéki fejlesztési programok 6,2\%-át fedezték kölcsön forrásokból.

Az Északnyugat-Dunántúl önkormányzatai - hasonlóan a vidék önkormányzatainak többségéhez - óvatosan bántak a hitelfelvétel lehetöségével az időszak elején. Az évtized elején jellemzöbb és relative olcsóbb víziközmủ beruházásokhoz kevésbé használtak hitelt, a céltámogatás mellé elégséges saját és egyéb forrást tudtak letenni a térség önkormányzatai. A csatornahálózat kiépitése viszont nagyobb erőfeszítést követelt meg az egyes közösségektöl, különösen, ha azt gázhálózat építés is kísérte. Ez a hitel igénybevétel fölértékelődéséhez vezetett ebben a régióban is (8. táblázat).

\section{TÁBLÁZAT}

A hitelezés jellemzöi az Északnyugat-Dunántíl megyéiben, 1993-1994 (\%)

The features of credits in the Nortwest Transdamubian counties, 1993-1994 (in per cent)

\begin{tabular}{|l|c|c|c|c|}
\hline Megyék & \multicolumn{2}{|c|}{$\begin{array}{c}\text { A felhalmozási kiadások hitel } \\
\text { felhasználási szintje }\end{array}$} & \multicolumn{2}{c|}{$\begin{array}{c}\text { A bevételek adósság-szolgálati } \\
\text { szintje }^{2}\end{array}$} \\
\hline & 1993 & 1994 & 1993 & 1994 \\
\hline Györ-Moson-Sopron & 0,4 & 3,5 & 3,6 & 4,5 \\
\hline Vas & 16,4 & 26,7 & 7,1 & 28,1 \\
\hline Veszprém & 2,2 & 13,6 & 10,3 & 12,4 \\
\hline Zala & 5,1 & 12,3 & 5,8 & 10,2 \\
\hline Régióöosszesen & 5,1 & 12,2 & 6,8 & 12,5 \\
\hline Megyék összesen & 9,6 & 18,1 & 9,8 & 15,4 \\
\hline
\end{tabular}

'Fejlesztési célú hitelfelvétel/Tárgyévi fejlesztési kiadások

${ }^{2}$ Kamatfizetés+Fejlesztési célú hiteltörlesztés/SZJA bevételek+helyi adó bevételek

Forrás: TÁKISZ adatbázis 
A korábban tárgyalt bevételi potenciálok helyzete tükrözödik vissza a térség önkormányzatainak hitelezési gyakorlatában. Ennek megfelelően csak a kevés összegü céltámogatást elérő, és az eddig viszonylag alacsony adókapacitást fölmutató Vas megye kényszerült legnagyobb mértékben fejlesztési célú hitelek fölvételére az utóbbi két évet figyelembe véve. 1993-ban még fejlesztéseik mintegy egyhatodát, 1994-re már több mint egynegyedét hitelböl finanszírozták a megye önkormányzatai. Ennek hatásai az adósságszolgálat szintjében már 1994-ben is jelentkeztek, de az igazán komoly terhek - nem növekvő hitelállomány esetén - az 1995-1997. években várható.

A régió többi megyéje a vidék átlagos mutatóinál lényegesen kedvezöbb helyzetet mutat, de itt sem szabad figyelmen kívül hagyni a hitel igénybevétel és az adósságszolgálat szintjének nővekedő trendjét. Ez különösen akkor jelenhet veszélyt, ha az SZJA bevételek súlya tovább csökken az önkormányzati bevételekben, miközben a helyi adók bevételi kapacitásának növelése is korlátozott.

Tovább javítja ezt a pozitiv képet az egyes önkormányzatok rövid tóvú pénzügypolitikája. Az ún. "betétezés" révén a térség megyéiben 2,5 Mrd Ft kamatbevételre tettek szert a helyi önkormányzatok 1993. és 1994. év során. Ez több, mint háromszorosa az ugyanezen években teherként jelentkező kamatkiadások összegének. Egyedül Vas megye tér el ismét jelentősebben a régióra jellemzö folyamatoktól, s 1994-ben a vasi önkormányzatok összesitett kamatterhei 16 MFt híján megegyeznek a lekötéseikért kapott kamatbevételekkel.

Ugyanakkor rontja a jövővel kapcsolatos várakozásokat az ÁHT-n belül megvalósítandó szigorúbb önkormányzati pénzellátási rendszer tervezett

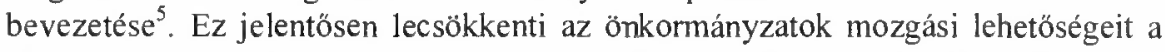
rövid távú pénzpiacokon, ugyanakkor tovább erösítheti a rövidtávú likviditási problémák áthidalására szolgáló müködési hitelek igénybevételét. Ezek törlesztése viszont az eddigi relatíve magas kamatbevételek elmaradása esetén problémákat is okozhat.

Összességében a fölsorolt források mintegy 75-80 Mrd Ft fejlesztéshez nyújthattak potenciálisan fedezetet (9. táblázat). Mivel a normatív támogatási rendszer nem fedi le teljes mértékben a kötelezően ellátandó feladatok költségeit (sőt meglehetősen eltérő mértékben képes finanszírozni azokat), így az általunk a különböző felhasználási célok között szabadon mozgathatónak itélt források mintegy egyharmadát a folyó kiadások emésztették föl. Ténylegesen $63 \mathrm{Mrd} \mathrm{Ft}$ fejlesztést eszközöltek a megye önkormányzatai az elmúlt négy évben, amelyhez több mint $20 \mathrm{Mrd}$ Ft kormányzati támogatást kaptak. Ez átlagosan 33,5\%-os - a vidéki átlagot $(32,1 \%)$ kismértékben meghaladó - támogatási arányt jelent. 


\section{TÁBLÁZAT}

Az önkormányzatok területfejlesztési forrásmérlege az Északnyugat-Dunántúlon, 1991-1994 (Mrd Ft)

Balance of the resources for regional development of the Nortwest Transdanubian local governments, 1991-1994 (billion HUF)

\begin{tabular}{|c|c|c|c|c|c|c|}
\hline & GY-M-S & Vas & Veszp. & Zala & Régió & Vidék \\
\hline Fejlesztési támogatások ${ }^{\prime}$ & 6,5 & 2,6 & 6,7 & 5,4 & 21,2 & 91,1 \\
\hline Átvett pénzeszkőzök ${ }^{2}$ & 2,9 & 1,3 & 1,5 & 1,3 & 7,0 & 36,7 \\
\hline Külsö források összesen & 9,4 & 3,9 & 8,2 & 6,7 & 28,2 & 127,8 \\
\hline Saját és "szabad" források ${ }^{3}$ & 14,3 & 8,7 & 13,7 & 10,3 & 47,0 & 261.6 \\
\hline Potenciális fejlesztési kapacitás & 23,7 & 12,6 & 21,9 & 17,0 & 75,2 & 389,4 \\
\hline $\begin{array}{l}\text { Fejlesztési, felhalmozási } \\
\text { kiadások }\end{array}$ & 19,0 & 11,7 & 17,6 & 14,9 & 63,2 & 283,9 \\
\hline Támogatottsági index $(\%)^{5}$ & 34,2 & 22,2 & 38,0 & 36,2 & 33,5 & 32,0 \\
\hline Saját források indexe $(\%)^{6}$ & 75,3 & 74,4 & 77,8 & 69,2 & 74,4 & 92,1 \\
\hline Fejlesztési célú hitelforrások & 0,9 & 2,0 & 1,5 & 1,4 & 5,7 & 37,5 \\
\hline Fejlesztések hiteligénye $(\%)^{8}$ & 4,7 & 17,1 & 8,5 & 9,4 & 9,0 & 13,2 \\
\hline \multicolumn{7}{|c|}{ 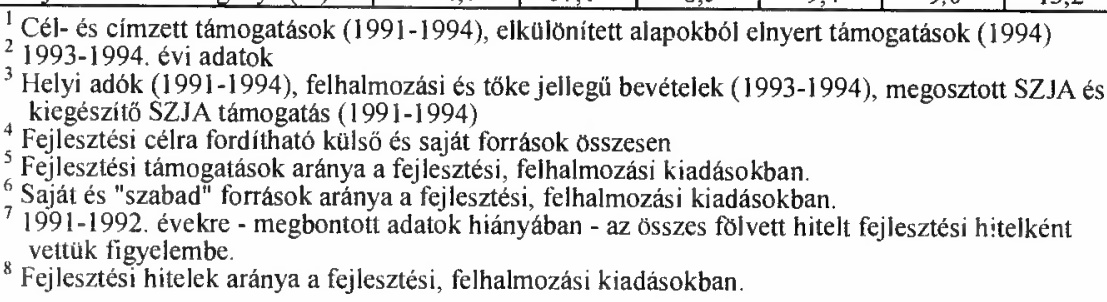 } \\
\hline
\end{tabular}

Forrás: TÁKISZ adatbázis

A fejlesztések forrásigényének további 10-15\%-át ${ }^{6}$ az ÁHT-n belülrỏl (központi szervek, más önkormányzatok) és az azon kívüli szereplöktől (vállalkozások, háztartások) fejlesztési célokra átvett bevételek biztosították. A fennmaradó 52$58 \%$-os rész négyötödét saját eröként, egyötödét pedig hitelforrásként vehetjük figyelembe.

A térség megyéi két alaptípusra bonthatók: aktív, illetve mérsékelt beruházási politikát folytató csoport. Az egyes csoportokba tartozást alapvetöen a potenciálisan fejlesztésre fordítható saját és egyéb szabadon mozgatható források szintje határozza meg. Ahol ezen források képződése átlagon felüli, azon megyék önkormányzatai nagyobb eséllyel kapcsolódhatnak be a pályázati rendszereken keresztül elnyerhetô források versenyébe. Vizsgált régiónkban Győr-Moson-Sopron, illetve Veszprém megye képviseli ezt a típust. Ez a csoport sem teljesen homogén, hiszen a fejlesztések hitelböl történő finanszírozási szintje lényegesen eltér egymástól. Ez a "szabad" forrásoknak müködési kiadásokkal való eröteljesebb leterheltségébỏl adódik. Veszprém megye esetében ezt a lekötöttséget kis mértékben növeli, az idöszak elejéröl származó - az átlagosnál magasabb adósság szolgálata.

A mérsékelt beruházási aktivitású csoport két megyéje is lényeges jegyekben eltér egymástól. Ennek hatásaként ebben a csoportban is a fejlesztések végső hiteligénye mutat jelentös különbséget. Zala megye fejlesztési forrás kapacitás szerkezete hasonlit a Veszprém megyeire. Mivel a megye önkormányzatai fejlesztési 
célkitűzéseiket a ténylegesen szabad forrás kapacitásaikhoz illesztették, ezért az átlagos fejlesztési hiteligényük is a Veszprém megyei önkormányzatok átlagához esik közelebb.

Vas megye a régió átlagánál gyengébb jövedelmi pozíciója következtében szerényebb mértékben részesülhetett a saját eröt feltételező központi támogatásokból. A szabad források müködési költségekkel való lekötöttsége miatt azonban ehhez a mérsékeltebb szintü - igaz a vidék átlagát meghaladó - fejlesztési elképzelések csak az átlagost lényegesen meghaladó hitelszinttel voltak biztosíthatók.

\section{Az Északnyugat-Dunántủl területfejlesztési erőforrásainak erös és gyenge pontjai}

Tanulmányunk az 1. ábrán fölvázolt modell keretei között kisérelte meg az Északnyugat-Dunántúl területfejlesztési forrásrendszerének föltárását. Vizsgálatunk a helyi önkormányzati felhalmozási tevékenységek forrásrendszerének elemzésére terjedt ki. Nem foglalkoztunk ugyanakkor a területfejlesztés másik két fö csoportjával a vállalkozásokkal és a háztartásokkal. Utóbbi az önerös lakásberuházásokon, valamint a közmüfejlesztések hozzájárulásán? keresztül kapcsolódik a terület- és településfejlesztéshez. Másoldalról, a háztartások jövedelmi helyzete alapvetően befolyásolja az önkormányzatok szabadon fölhasználható, a felhasználási célok között mozgatható forrásainak képződését, egyrészt az SZJA befizetéseken, másrészt a potenciális helyi adó kapacitáson keresztül.

Nem terjedt ki a jelen vizsgálat az intézményrendszer finomszerkezetének vizsgálatára sem. Így például az önkormányzatok esetében, a megyei önkormányzatok és a települési önkormányzatok, illetve az egyes település típusok (nagy-, közép- és kisvárosok, különbözö népesség nagyságrendü községek) területfejlesztési akcióinak egyenkénti értékelésére. A megyei önkormányzatokat területfejlesztési tevékenysége két irányú. Egyrészt a saját intézményrendszer fejlesztését, másrészt bizonyos térségi programok menedzselését foglalta magába.

Ez utóbbit azonban a megyék önként vállalt feladatként végezték az elmúlt négy évben, hiszen ehhez az önkormányzati szabályozási rendszer nem biztosított törvényi hátteret. Ennek megfelelöen az egyes megyékben, s ez az ÉszaknyugatDunántúlra is érvényes, rendkívül eltérỏek voltak az ilyen típusú ráfordítások. A különbségek részben a térségi szintü ágazati-területi fejlesztési koncepciókra történt ráforditásokkal mérhetök. E tekintetben Györ-Moson-Sopron megye önkormányzata járt az élen a térségen belül. Ebben a megyében szintén jellemzó volt, hogy a céltámogatást megpályázó, több önkormányzatot átfogó programokat a megyei önkormányzat a pályázó településcsoport saját részét erősitó pénzeszköz átadással, tervezési költség átvállalással segítette.

A számszerúen kevesebb regionális fejlesztési koncepció nem feltétlenül jelent gyenge térségszervezö aktivitást. Vas megye a határmenti kapcsolatok építésében, Zala megye a kistérségi szervezödések ösztönzésében, Veszprém megye pedig a megyei önkormányzat érdekvédelmének (pl. A Comitatus c. folyóirat alapításával, 
az abban képviselt szellemmel) képviseletében mutathat föl számottevő eredményeket.

A területfejlesztés megyei önkéntessége a megyék pénzügyeiben is tükröződik, hiszen annak forrásképzését nem építették be a megyei önkormányzatok finanszírozási rendszerébe. Ezért nem terjedt ki az önkormányzatok adóztatási jogosítványa a megyei önkormányzatokra, $\mathrm{s}$ nem részesültek a megyék az SZJA jövedelmekböl.

Az utóbbi 5-10 évben számos új szereplỏ is megjelent a terület- és településfejlesztésben. Ilyenek a civil szervezödések (egyesületek), a non-profit szervezetek (alapítványok, kistérségi szövetségek), valamint olyan non-profit vagy profitorientált szervezetek, amelyek közvetítöként jelennek meg a területfejlesztés hagyományos szereplői között (vállalkozásfejlesztési alapítványok rendszere, regionális fejlesztési társaságok, kockázati tőke társaságok stb.). Ezekkel sem foglalkozott a fejezet. Ezt részben (pl. civil szerveződések, kistérségi szövetségek) megtették más fejezetek, részben pedig olyan új szervezetekröl van szó, amelyek térségünkben még meg sem jelentek (pl. a Borsod-Abaúj-Zemplén és SzabolcsSzatmár megyében PHARE támogatással, a Területfejlesztési törvényt megalapozó pilot projektként bevezetett megyei fejlesztési tanácsok és az azokhoz kapcsolódó megyei fejlesztési ügynökségek).

A fenti szerveződések jelentős mértékben kitágítják a jövőben a fejezet elején fölvázolt modellt. Egyre eröteljesebbé válnak a szereplök és a források közötti-már ma is tapasztalható - keresztkapcsolatok. Kulcsszerephez juthatnak a közvetító szervezetek, amelyek formája adott célokhoz igazodva, egyaránt lehet alapitvány, társaság. Ezek a szervezetek lesznek képesek a három alapszereplö - vállalkozások, költségvetés, háztartások - érdekeinek közös és priorizált célrendszerbe foglalására, valamint az ehhez szükséges források összevonására. Ez a rendszer aktiv partnerséget feltételez valamennyi érdekelt szereplötől.

$A z$ elemezés fölvázolt korlátait figyelembe véve megrajzolhatók a területfejlesztés forrásainak erős és gyenge pontjai a régióra vonatkozóan (10. táblázat), amelyek alapul szolgálhatnak a régió fejlesztési programrendszere forrásszerkezetének tervezéséhez. 


\section{TÁBLÁZAT \\ Északnyugat-Dunántúl területfejlesztési forrásainak erös és gyenge pontjai Strengths and weaknesses of the regional development resources of Nortwest Transdanubia}

\begin{tabular}{|c|c|}
\hline ERÖS PONTOK & GYENGE PONTOK \\
\hline $\begin{array}{l}\text { - Intenzív beruházási tevékenység mind a } \\
\text { vállalkozások, mind az önkormányzatok } \\
\text { részéröl }\end{array}$ & $\begin{array}{l}\text { - Az átlagoshoz képest alacsony részarányú és } \\
\text { reálértékben csökkenö lakossági beruházások } \\
\text { (Györ-Moson-Sopron, Vas) }\end{array}$ \\
\hline $\begin{array}{l}\text { - Aktívan pályázó vállalkozók és } \\
\text { önkormányzatok a (terület)tejlesztés } \\
\text { támogató alapokhoz }\end{array}$ & $\begin{array}{l}\text { - Nehéz hozzáférhetỏség a TEFA-hoz a } \\
\text { régió megyéi részéröl }\end{array}$ \\
\hline $\begin{array}{l}\text { - Gazdasági vonzerõ növelése fejlett gazda- } \\
\text { sági infrastruktúra kiépitésén keresztül }\end{array}$ & $\begin{array}{l}\text { - Innovációt segitõ alapok mérsékelt } \\
\text { igény bevétele }\end{array}$ \\
\hline $\begin{array}{l}\text { - Magas céltánogatási arány elérése (kivéve } \\
\text { Vas megye) }\end{array}$ & $\begin{array}{l}\text { - Függőség a céltúmogatási rendszertól a } \\
\text { helyi területfejlesztési politikákban }\end{array}$ \\
\hline $\begin{array}{l}\text { - A szabad és saját források átlagot meg- } \\
\text { haladó részarány növekedése, múködési } \\
\text { költségekkel való alacsonyabb fokú } \\
\text { terheltsége }\end{array}$ & $\begin{array}{l}\text { - Erösen fluktuáló összegü, az összbe- } \\
\text { vételben leértékelödõ SZJA források }\end{array}$ \\
\hline $\begin{array}{l}\text { - Aktiv helyi adópolitika (Veszprém megye } \\
\text { és a régió városai) }\end{array}$ & $\begin{array}{l}\text { - Alacsony községi helyi adó kapacitás } \\
\text { (Györ-Moson-Sopron, Vas, Zala) }\end{array}$ \\
\hline $\begin{array}{l}\text { - A felhalmozási és tökejellegï bevételek } \\
\text { (vagyonhasznositás, privatizáció, kamat- és } \\
\text { osztalék bevételek) gyors növekedése }\end{array}$ & $\begin{array}{l}\text { - Értékesités dominanciája a vagyon- } \\
\text { hasznositásban (vagyonfelélés) }\end{array}$ \\
\hline $\begin{array}{l}\text { - Nincs eladósodási veszély a régió ön- } \\
\text { kormányzatainál }\end{array}$ & $\begin{array}{l}\text { - Magas hiteligény egyes önkormányzatok } \\
\text { fejlesztéseinél (Vas megye) }\end{array}$ \\
\hline
\end{tabular}

\section{Jegyzetek}

1 Van olyan önkormányzat is, amely magasabb adósságállományt halmozott föl az elmúlt négy évben, mint egy évi teljes költségvetése.

${ }^{2}$ Nem volt ez másképpen a fejlett országok 1970-1980-as években lezajlott közigazgatási decentralizációja esetében sem. Az önkormányzat nem teljes költségfedezetet kapott az új feladattal, hanem annak lehetóségét, hogy saját bevételeket generáljon. (Benett 1992)

${ }^{3}$ Ettöl csak olyan kivételes esetekben tértek el, mint a Szigetköz csatornahálózati programja, amelyet a Bös-Nagymarosi Vizlépcső beruházás kárenyhítő beruházásai közé soroltak és a központi hányad maximumát $60 \%$-ban határozták meg. Így a Szigetköz települései $1 \mathrm{Mrd} F t$ extra céltámogatáshoz jutottak az általános 40\%-os támogatást meghaladó szubvenció révén (Lados-Rechnitzer 1994)

4 1990. évi C. Törvény

5 Természetesen ez nem egy önmagáért való megszoritás az önkormányzatok felé. Az eljárás az állam rővid lejáratú hiteligényét (pl. kincstárjegy kibocsátás), s ezáltal az államadósság és annak kamatterheit csökkenti.

${ }^{6}$ Mivel erröl a bevétel típusról csak a legutóbbi két év adataival rendelkezünk, az 1991-1992. évi országos összesen adatok, valamint az 1993-1994. évi adatok területi eloszlása alapján max. 5\%-kal emelkedhet ennek a forrás típusnak a részaránya a fejlesztések fedezetében a két év alapján számitoit $10 \%-0$ s részesedéshez képest.

${ }^{7}$ A vidék összességét tekintve 12,5 Mrd Ft-ot adott át a lakosság fejlesztési célokra az önkormányzatoknak 1993-1994. években. Régiónkban 1,7 Mrd Ft-ot tett ki ez a forrás, amely a vidéki átlagnál kisebb mértékü lakossági hozzájárulást jelez, s amely a két év önkormányzati beruházási ráfordításainak mintegy $6 \%$-hoz nyújtott fedezetet. 


\section{Irodalom}

Bennett (1990) Decenralisation, Local Governemnts and Markets: Towards a Postwelfare Agenda. Calderon Press, Oxford.

Beretvás M.-né (1995) A vállalkozások beruházási tevékenysége Györ-Moson-Sopron megyében a kilencvenes évek elsö felében. MTA RKK NYUTl, Györ. Kézirat 300.

Fehérvári (1995) A helyi adók - Müködési tapasztalatok. Önkorkép. 5-6. sz. 12-15. o.

Illés I. ( I993) Az önkormányzatok finanszirozásának aktuális problémái. Magyar Közigazgatás. 9. sz. 522-525. o.

Lados M. (1990) Change in the Economic Operation of the Local Authorities in the City of Györ. In: Events and Changes - The First Steps of Local Transition in East-Central Europe. Editor: Péteri, G. Budapest, Local Democracy and Innovation Foundation. 172-184. o.

Lados M. - Rechnitzer J. (1994) A Szigetközt érintő gazdasági károk - vállalkozások, idegenforgalom, infrastruktúra. Tanulmányok, Elemzések, Dokumentumok, Javaslatok 42. sz. MTA RKK ÉDO, Györ. - kutatási zárójelentés + angol nyelvúu összefoglaló

Lados M. (1994) Ingatlanvagyon adóztatás az önkormányzati gazdálkodásban. Tanulmányok. Elemzések, Dokumentumok, Javaslatok 47. sz. MTA RKK ÉDO, Györ.

Lados M. (1995) A területfejlesztés forrásai. In: Északnyugat-Dunántúl fejlesztési stratégiája. NYUT1 Közleményei 13. sz. II. kötet 489-531. o.

Pitti - Varga (1995) Az önkormányzatok vagyonosodási folyamata. KJK, Budapest

Péteri G. (szerk.) (1994) Központi-helyi költségvetési kapcsolatok. USAID, Budapest.

Várfalvi - Farkas S.-né - Lacó B. - Mrkvicskáné (1993) A helyi önkormányzatok gazdálkodása és az államháżtartási törvény. Perfekt, Budapest.

Vigvári (1994) A magyarországi települési önkormányzatok helyzete. Budapest Bank Tanulmányok 17. Budapest.

Világbank (1995) Magyarország - Szerkezetváltás és tartós növekedés. Világbank, Washington D.C.

\section{LOCAL GOVERNMENT MANAGEMENT AND REGIONAL DEVELOPMENT IN NORTHWEST TRANSDANUBIA}

\section{MIHÁLY LADOS}

The essay attempts to assess what resources the governments of Northwest Transdanubia - i.e. Györ-Moson-Sopron, Vas, Veszprém and Zala counties - used in order to achieve their regional development objectives in the first half of the 1990s. The author measures regional development with the investment and accumulation activity of the local governments. After the Budapest agglomeration, this is the region where the concentration of inward investments is the most intensive. The examined four counties are home to one-sixth of the countryside population of Hungary, at the same time more than one-fifth of all national investments addressed this region between 1991 and 1994. Looking at the local governments only, this concentration is slightly less expressed (19\%). During the four years, approximately 60 billion HUF of local government investment was carried out from many different resources: Own resources, divided revenues, central supports, acquisition of financial means and credit.

On the whole, the resources listed above could provide investments worth 75-80 billion HUF. As the system of normative grants does not totally cover the costs of the obligatory responsibilities, approximately one-third of the resources which we 
though could be freely mobilised among the different purposes was consumed by running expenses. The actual amount of investments by the local governments in the past four years amounted to 63 billion HUF, supplemented by more than 20 billion HUF central government support. This is an average of 33,5\% rate of support, slightly over $(32,1 \%)$ the countryside average. Another $10-15 \%$ of the necessary resources came from within the State organisation (central organs, other local governments) and from the outside (businesses, households). Three-quarters of the remaining $52-58 \%$ share can be considered as own resources, one-fifth as credits.

The counties of Nortwest Transdanubia can be divided into two sub-groups: a group with an active and another one with a moderate investment policy. The belonging to either group is mainly determined by the level of own and other mobile resources which can potentially be spent on development. Where the generation of these incomes is above the average, the county governments have better chances when joining in the competition for the resources that are available through applications. In the Northwest Transdanubian region it is Gyorr-Moson-Sopron and Veszprém which represent this type. This group is not totally homogeneous, either, as the level of the financing from credits considerably varies across the two counties. This comes from the more intensive dependence of the "free" resources on running expenses. In Veszprem county this dependence is slightly increased by the debts from the beginning of the period, which are slightly higher than the average.

The two counties in the group with moderate investment activity differ from each other in important features, too. In this group too it is the final credit demand of the developments that shows significant differences. The structure of the development resources of Zala resembles that of Veszprém county. As the local government of the county adjusted their development objectives to the actual capacity of their free resources, their average demand for credit in their developments is closer to the average of the local governments of Veszprém county, too.

Vas county, as a result of its income conditions weaker than the average of the region, could only have a more moderate share from the state supports which required a certain amount of own resources as well. Because of the dependence of the free resources on the running expenses, however, even these smaller scale development objectives - which nevertheless exceeded the average of the countryside - could only be provided with a level of credits significantly higher than the average. 